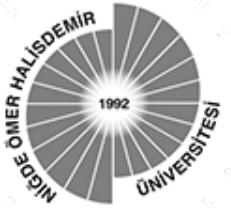

Araştırma Makalesi Research Article
Ömer Halisdemir Üniversitesi İktisadi ve İdari Bilimler Fakültesi Dergisi

Yll: 2020 Cilt-Sayı: 13(3) ss: 477-491

Academic Review of Economics and Administrative Sciences

Year: 2020 Vol-Issue: 13(3) pp: 477-491

http://dergipark.org.tr/tr/pub/ohuiibf/

\title{
Bilgi YoĞun Hizmetler Alt Sektörlerinde ÖĞRENME EĞRÍLERİ
}

\author{
Gürkan ÇALMAŞUR ${ }^{1}$ \\ Hüseyin DASTTAN ${ }^{2}$ \\ Zeynep KARACA ${ }^{3}$
}

$\ddot{O} z$

Öğrenme eğrisi, firmanın kümülatif toplam üretimi arttıķ̧a ortalama maliyetlerindeki düşüşü göstermektedir. Tek değişkenli ve çok değişskenli olmak üzere farklı ögrenme eğrisi modelleri vardır. Geleneksel tek değişkenli öğrenme eğrisi, üretim maliyeti gibi bir bağımlı değişkeni kümülatif üretim miktarı vb. Băğısıı değişkenler açısından açıklamaya çalı̧̧maktadır. Tek değişkenli modeller arasında Log-Lineer model, S-eğrisi, StanfordB modeli, DeJong'un öğrenme formülü, Levy'nin adaptasyon fonksiyonu, Glover'n ögrenme formülü, Pegel'in üstel fonksiyonu, Knecht'in yükselme modeli, Yelle'nin ürün modeli sayllabilir. Söz konusu modeller içinde $S$ ĕgrisi veya kübik ögrenme modeli, öğrenme seviyesinin zaman içinde değiştiğini varsaymaktadır. Öğrenme eğrileri geleneksel olarak sanayi ve hizmet sektörlerinde kullanilmaktadır. Hizmetler sektörü, nihai ürünlerden ziyade hizmetin üretildiği bir endüstri koludur. Bu çalışmanın ana amacı, 2003-2017 dönemi için Türk Bilgi Yoğun Hizmetler alt sektörlerine ait öğrenme eğrilerini detaylı bir biçimde analiz etmektir. Bu amacı gerçekleştirmek için kübik ögrenme modeli, 2003 ve 2017 yllları arasında Bilgi Yoğun Hizmetler alt sektörleri için ögrrenme (ilerleme) oran değerleri tahmin edilmişs ve hesaplanmıştır. Çalışmadan elde edilen bulgulara göre, Bilgi Yoğun Hizmetler sektörlerinde her bir alt sektördeki öğrenme eğrisinin dlş bükey, içbükey, negatif ve pozitif eğimli olmak üzere dört farklı şekle sahip olduğu görülmüş̧ür.

$\begin{array}{ll}\text { Anahtar Kelimeler } & : \text { Öğrenme Ĕ̆risi, Öğrenme (ïlerleme) Oranı, Bilgi Yoğun Hizmetler, Türkiye. } \\ \text { Jel Sinıflandirılması } & : \text { D83, L80. }\end{array}$

\footnotetext{
${ }^{1}$ Doç. Dr., Erzurum Teknik Üniversitesi, İ.İ.B.F., İktisat Bölümü, gurkan.calmasur@erzurum.edu.tr, ORCID: 0000-0002-8515-5719

${ }^{2}$ Doç. Dr., Erzurum Teknik Üniversitesi, İ.İ.B.F., İktisat Bölümü, hdastan@erzurum.edu.tr, ORCID: 0000-0001-8016-7145

${ }^{3}$ Dr Öğr. Üyesi., Erzurum Teknik Üniversitesi, İ.İ.B.F., İktisat Bölümü, zeynep.karaca@erzurum.edu.tr, ORCID: 0000-0001-8046-7222
} 


\title{
LeARning CuRves In The KNOWLEDGe INTENSIVE Services Sub-Sectors
}

\begin{abstract}
The learning curve illustrates the decrease in average cost as the cumulative total output of the firm increases. There are different learning curve models including univariate and multivariate. The traditional univariate learning curve symbolizes a dependent variable such as production cost in terms of independent variables (cumulative output, etc.). The univariate models are the log-linear model, the S-curve, the Stanford-B model, DeJong's learning formula, Levy's adaptation function, Glover's learning formula, Pegel's exponential function, Knecht's upturn model, and Yelle's product model. Among these models, the S-curve or cubic learning model assumes that the level of learning varies over time. The learning curves have traditionally been used for industry and service sectors. Service sector is the branch of industry in which the service is produced rather than the final goods. The main aim of this study is to make a detailed analysis the learning curves in the Turkish Knowledge Intensive Services sub-sectors for 2003-2017 period. In order to satisfy this aim, the cubic learning model has been estimated and calculated the learning (progress) ratio values Knowledge Intensive Services sub-sectors from 2003 to 2017. According to the findings obtained from the study, it was observed that the learning curve in the Knowledge Intensive Services sectors in each sub-sector has four different shapes, convex, concave, negative and positive slope.
\end{abstract}

Keywords : Learning Curve; Learning (Progress) Ratio, Knowledge Intensive Services, Turkey.

Jel Classification: D83, L80.

\section{GİRIŞ}

Bilgi yoğun hizmetler sektörü, gerek sağladığı istihdam ve gerekse ihracata yönelik katkıları sebebiyle Türkiye ekonomisinde ekonomik kalkınma ve yenilikçilik faaliyetlerinin gerçekleştiği önemli bir konumda yer almaktadır. Sektör, kendi içerisinde birçok alt sektöre ayrıldığı için homojen bir yapıya sahip değildir. Dolayısıyla ilgili alt sektörlerde yaşanan değişim ve gelişimlerin ayrı ayrı incelenmesi ve yorumlanması gerekmektedir. Bu bağlamda, bilgi yoğun hizmetler alt sektörlerinde yaşanan ekonomik, teknolojik vb. gelişim ve değişimlerin bilinmesi önem arz etmektedir. Bu çalışmada, Bilgi yoğun hizmetler alt sektörlerinin teknolojik öğrenme seviyelerinin tespit edilmesi amaçlanmıştır.

Firmalar zaman içerisinde daha fazla mal veya hizmet ürettiklerinde, birim üretim maliyeti genellikle azalan oranda bir seyir izlemektedir. Bu olgu, öğrenme eğrisi veya deneyim eğrisini ifade etmektedir (Argote \& Epple, 1990: 920). Öğrenme eğrisi, İkinci Dünya Savaşı sırasında yetkililer tarafından savaşı yürütmek için kullanılacak gemi ve uçakların inşaat maliyetleri ve zaman gereksinimlerini tahmin etmek amacıyla kullanılarak dikkat çekmeye başlamıştır (Yelle, 1979: 303). Yapılan analizler neticesinde, üretilen kümülatif uçak sayısı arttıkça uçak başına isabet eden işgücü girdisinin kayda değer bir biçimde düzenli olarak azaldığı keşfedilmiştir (Krajewski, Malhotra, \& Ritzman, 2019: I-2). 1925 y1lında askeri bir fabrikada gözlemlenen bu öğrenme olgusu 1936 yılında ampirik bir teori olarak şekillenmiştir. 1936 yılında Wright, öğrenme eğrisi üzerindeki ampirik bulgularını açıklamıştır. Wright'ın bulgularına göre, uçak üretiminin her iki katına çıkmasıyla birlikte işgücü girdi gereksinimi yaklaşık olarak \%20 oranında azalmaktadır (Asgari \& Yen, 2009: 77).

Uçak üretim alanında keşfedilen kümülatif üretim miktarının artmasıyla birlikte işgücü maliyetinde gerçekleşen \%20 civarındaki bu azalışın birinci nedeni, işçilerin aynı işi devamlı olarak yapmaları sonucunda, söz konusu işi daha az zamanda yapmayı başarmalarıdır. İkinci neden ise, yine aynı işi sürekli olarak gerçekleştiren personelin daha etkin yöntemler geliştirmesidir. Tecrübe ile birlikte sağlanan bu maliyet azalışı zamanla daha da yaygınlaşmıştır (Dinler, 2019: 229).

Öğrenme veya deneyim eğrileri, uçak, beyaz eşya, gemi, bilgisayar çipleri, rafine petrol ürünleri vb. malların üretim faaliyetini gerçekleştiren imalat ve hizmet sanayilerinde yaygın bir 
biçimde uygulanmıştır. Ayrıca, söz konusu eğriler işgücü, malzeme ile hammadde ihtiyacını tespit etmek, üretim sürecini planlamak amacıyla da kullanılmaktadır. Son olarak, mal veya hizmetlerin satılacağı fiyatı tespit etmek ve hatta tedarikçilerin fiyat tekliflerini değerlendirmek için bile öğrenme eğrilerinden faydalanılmaktadır (Salvatore, 2003: 251-252).

Tek değişkenli ve çok değişkenli olmak üzere farklı öğrenme eğrisi modelleri vardır. Geleneksel tek değişkenli öğrenme eğrisi, bazı bağımsız değişkenler (kümülatif üretim miktarı, vb.) ile bağımlı bir değişkeni (üretim maliyeti) açılamaya çalışmaktadır. Log-lineer model, S-eğrisi, Stanford-B modeli, DeJong modeli, Levy modeli, Glover modeli, Pegel modeli, Knecht modeli, Yelle modeli ve Çarpımsal güç modeli tek değişkenli modeller arasında yer almaktadır (Badiru, 1992: 176).

Bu çalışmanın ana amacı, NACE Rev.2 (İkili Düzey) ekonomik faaliyet sınıflandırması altında 2003-2017 dönemi için Türkiye özelinde Bilgi Yoğun Hizmetler alt sektörlerinde gerçekleşen öğrenme düzeyini analiz etmektir. Bu bağlamda, Bilgi Yoğun Hizmetler alt sektörlerindeki ilerleme (öğrenme) oranlarının tahmin edilmesinde kübik öğrenme modeli kullanılmıştır. Literatürde, Türkiye özelinde Bilgi yoğun hizmetler alt sektörleri için öğrenme eğrisini analiz eden herhangi bir çalışmaya pek rastlanamamıştır. Dolayısıyla bu çalışmanın ilgili alt sektörler için ilk defa gerçekleştirilecek olmasının, çalışmayı özgün kıldığı düşünülmektedir. Çalışma beş ana bölümden oluşmaktadır. İkinci bölümde, konu ile ilgili literatür taraması sunulmaktadır. Üçüncü bölümde makalenin veri ve metodolojisi açıklanmaktadır. Dördüncü bölümde, imalat sanayi alt sektörlerinin teknolojik öğrenme düzeylerine tespitinde elde edilen ampirik bulgular özetlenmiş ve yorumlanmıştır. Beşinci ve son bölümde ise çalışmanın sonuçlarına yer verilmiştir.

\section{LITERATÜR ÖZETİ}

Literatürde öğrenme eğrisi modellerini analiz eden yerli ve yabancı birçok çalışmaya rastlamak mümkündür. Söz konusu çalışmalarda genel olarak kümülatif üretim miktarının artışıla birlikte üretim maliyetlerinin zaman içerisinde azaldığ tespit edilmiştir. Tablo 1'de, öğrenme eğrisi modelini analiz eden yerli ve yabancı çalışmalardan bazıları kronolojik olarak ifade edilmektedir.

Tablo 1: Öğrenme Eğrisini Analiz Eden Bazı Çalışmalar

\begin{tabular}{|l|l|l|l|l|l|}
\hline \multicolumn{1}{|c|}{ Yll } & \multicolumn{1}{|c|}{ Yazar } & \multicolumn{1}{c|}{ Sektör } & \multicolumn{1}{c|}{ Yll } & \multicolumn{1}{c|}{ Yazar } & \multicolumn{1}{c|}{ Sektör } \\
\hline 1936 & Wright, T. P. & Uçak & 2000 & Sinclair, G. vd. & Kimyasal \\
\hline 1965 & Hartley, K. & 2000 & Tan, W. \& Elias, Y. & İnşaat \\
\hline 1973 & Boston Consulting Group & Yarı İletken & 2002 & Pramongkit, P. vd. & İmalat \\
\hline 1971 & Baloff, N. & $\begin{array}{l}\text { Otomobil, tekstil } \\
\text { ve büyük müzik } \\
\text { aletleri }\end{array}$ & 2001 & Chung, S. & Yarletken \\
\hline 1972 & Dudley, L. & Metal & 2003 & $\begin{array}{l}\text { Franceschini, F. \& Galetto, } \\
\text { M. }\end{array}$ & İmalat \\
\hline 1974 & Sultan, R. & Buhar türbini & 2004 & Goldemberg J. vd. & Etanol \\
\hline 1984 & Lieberman, M. B. & Kimyasal & 2005 & Karaoz, M. \& Albeni, M. & İmalat \\
\hline 1990 & Argote, L. \& Epple, D. & Uçak & 2009 & Asgari, B. \& Yen, L. W. & İmalat, Hizmet \\
\hline 1990 & Argote L. vd. & Gemi & 2010 & Nadeau, M. C. vd. & Hidroforming \\
\hline 1991 & Dick, A. R. & Yarı İletken & 2012 & $\begin{array}{l}\text { Asgari, B. \& Gonzalez- } \\
\text { Cortez, J. L. }\end{array}$ & İmalat \\
\hline 1994 & Jarmin, R. S. & Suni ipek & 2018 & Aduba, J. J. \& Izawa, H. & $\begin{array}{l}\text { İmalat -İmalat } \\
\text { diş1 }\end{array}$ \\
\hline
\end{tabular}

Wright, 1936 yılında öğrenme eğrisi modelini ampirik olarak analiz eden ilk araştırmacıdır. Wright (1936), uçak endüstrisindeki üretim maliyetini araştırmıştır. Wright, uçak üretimindeki birim işçilik maliyetlerinin kümülatif üretim artışı ile beraber düştüğünü tespit etmiştir. Wright'ın yapmış 
olduğu çalışmadan günümüze kadar, öğrenme eğrisi modelleri tablo 1'den de görüldüğü üzere farkl1 sektör ve alanlarda yaygın bir biçimde kullanılmaktadır.

Öğrenme eğrisi teorisi, Boston Consulting Group (1970) tarafindan değiştirilmiş ve deneyim eğrisi kavramı ortaya çıkmıştır. Orijinal öğrenme eğrisi yaklaşımı, üretim sürecindeki sadece tek bir girdiyi göz önünde bulundururken, deneyim eğrisi kavramı, öğrenmenin sadece bir üretim faktörünü değil aksine üretim sürecindeki tüm üretim faktörlerini içermesi gerektiğini ifade etmektedir. Boston Consulting Group, öğrenme analizinin tek bir fabrika ortamından endüstriyel seviyeye genişletilmesine de olanak sağlamıştır (Karaöz \& Albeni, 2005: 870). Spence (1981) ile Kalish (1983) gibi araştırmacılar ise fiyat ve üretim miktarının belirlenmesinde öğrenme eğrisinin nasıl kullanılabileceğini göstererek yüksek teknolojik öğrenme seviyesine sahip bir firmanın herhangi bir sektördeki diğer firmalardan daha fazla üretmesi gerektiğini tespit etmişlerdir (Majd \& Pindyck, 1989: 331). Anzanello \& Fogliatto (2011), öğrenme eğrisi modelleriyle ilgili kapsamlı bir literatür taraması sunmaktadır.

Günümüzde, özellikle iş dünyasının da içinde yer aldığ modeli değerlendirilmekte ve öğrenme eğrisi modelleri içerisinde ise log-doğrusal model yaygın olarak kullanılmaktadır. Bu sebeple çalışmamızda Türkiye'de Bilgi Yoğun Hizmetler alt sektörlerinin teknolojik öğrenme düzeylerini ve bu sayede öğrenme eğrilerini tespit etmek için logdoğrusal model içerisinde değerlendirilen kübik öğrenme eğrisi modeli kullanılmıştır.

\section{METODOLOJI}

Bilgi yoğun hizmetler alt sektörlerine ilişkin veriler, Türkiye İstatistik Kurumu (TÜİK)'ndan elde edilmiştir. Veri seti, 2003-2017 dönemine ilişkin y1llık veri setini kapsamaktadır. Çalışmada, üretim miktarını temsil etmek için üretim değeri ve işgücünü ifade etmek için ise personel maliyeti değişkenleri kullanılmıştır. Söz konusu veriler parasal verilerdir. İlgili değişkenleri reel hale getirmek yani fiyat etkisinden arındırmak için TÜİK tarafından yayınlanan Tüketici Fiyat İndeksi (TÜFE 2003=100) ile deflate edilmiştir.

Eurostat bilgi yoğun hizmetler üreten alt sektörleri, Tablo 2'de gösterildiği gibi altı grupta sınıflandırmıştır. Söz konusu sınıflandırmada yer alan alt sektörlerden bazılarına ilişsin veriler Türkiye özelinde bulunmadığı için analizlerde bazı alt sektörler yer almamaktadır. Örneğin, bilgi yoğun finansal hizmetler kategorisinde veri bulunmadığ için bu alt sektörlere ilişkin herhangi bir analiz yapılamamıştır.

Tablo 2: Bilgi Yoğun Hizmetler Faaliyetlerinin Eurostat Sınıflandırması

\begin{tabular}{|c|c|}
\hline $\begin{array}{c}\text { Yüksek Teknoloji ve Finansal Hizmetleri İçeren } \\
\text { Bilgi Yoğun Piyasa Hizmetleri }\end{array}$ & Diğer Bilgi Yoğun Hizmetler \\
\hline Su yolu taşımacilığı $(50)$ & Yayımcılık faaliyetleri (58) \\
\hline Hava yolu taşımacılığı (51) & Veterinerlik hizmetleri (75) \\
\hline Hukuk ve muhasebe faaliyetleri (69) & Kamu yönetimi ve savunma; zorunlu sosyal güvenlik (84) \\
\hline İdare merkezi faaliyetleri; idari danışmanlık & Eğitim (85) \\
\hline faaliyetleri (70) & İnsan sağlığı hizmetleri (86) \\
\hline Mimarlık ve mühendislik faaliyetleri; teknik & Yatılı bakım faaliyetleri (87) \\
\hline muayene ve analiz (71) & Barınacak yer sağlanmaksızın verilen sosyal hizmetler (88) \\
\hline Reklamcılık ve piyasa araştırması (73) & Yaratıcı sanatlar, gösteri sanatları ve eğlence faaliyetleri (90) \\
\hline Diğer mesleki, bilimsel ve teknik faaliyetler (74) & Kütüphaneler, arşivler, müzeler ve diğer kültürel faaliyetler (91) \\
\hline İstihdam faaliyetleri (78) & Kumar ve müşterek bahis faaliyetleri (92) \\
\hline Güvenlik ve soruşturma faaliyetleri (80) & Spor faaliyetleri, eğlence ve dinlence faaliyetleri (93) \\
\hline Daha Az Bilgi Yoğun Piyasa Hizmetleri & $\begin{array}{c}\text { Bilgi Yoğun Finansal Hizmetler } \\
\end{array}$ \\
\hline $\begin{array}{l}\text { Motorlu kara taşıtlarının ve motosikletlerin toptan } \\
\text { ve perakende ticareti ile onarımı }(45) \\
\text { Toptan ticaret (Motorlu kara taşıtları ve }\end{array}$ & $\begin{array}{l}\text { Finansal hizmet faaliyetleri (Sigorta ve emeklilik fonları hariç) (64) } \\
\text { Sigorta, reasürans ve emeklilik fonları (Zorunlu sosyal güvenlik } \\
\text { hariç) (65) }\end{array}$ \\
\hline
\end{tabular}




\begin{tabular}{|c|c|}
\hline \multirow{2}{*}{$\begin{array}{l}\text { motosikletler hariç) (46) } \\
\text { Perakende ticaret (Motorlu kara taşıtları ve }\end{array}$} & $\begin{array}{l}\text { Finansal hizmetler ile sigorta faaliyetleri için yardımcı faaliyetler } \\
\text { (66) }\end{array}$ \\
\hline & $\begin{array}{c}\text { Yüksek Teknoloji Bilgi Yoğun Hizmetler } \\
\end{array}$ \\
\hline $\begin{array}{l}\text { Kara taşımacıllı̆̆ ve boru hattı taşımacılığ }(49) \\
\text { Taşımacılık için depolama ve destekleyici } \\
\text { faaliyetler (52) } \\
\text { Konaklama (55) } \\
\text { Yiyecek ve içecek hizmeti faaliyetleri (56) } \\
\text { Gayrimenkul faaliyetleri (68) } \\
\text { Kiralama ve leasing faaliyetleri (77) } \\
\text { Seyahat acentesi, tur operatörü ve diğer }\end{array}$ & $\begin{array}{l}\text { Sinema filmi, video ve televizyon programları çekim sonrası } \\
\text { faaliyetleri (59) } \\
\text { Programcılık ve yayıncılık faaliyetleri (60) } \\
\text { Telekomünikasyon (61) } \\
\text { Bilgisayar programlama, danışmanlık ve ilgili faaliyetler (62) } \\
\text { Bilgi hizmet faaliyetleri (63) } \\
\text { Bilimsel araştırma ve geliştirme faaliyetleri (72) }\end{array}$ \\
\hline rezervasyon hizmetleri ve ilgili faaliyetler (79) & Diğer Daha Az Bilgi Yoğun Hizmetler \\
\hline $\begin{array}{l}\text { Binalar ile ilgili hizmetler ve çevre düzenlemesi } \\
\text { faaliyetleri ( } 81) \\
\text { Büro yönetimi, büro destek ve iş destek faaliyetleri } \\
\text { (82) } \\
\text { Bilgisayarların, kişisel eşyaların ve ev eşyalarının } \\
\text { onarımı (95) }\end{array}$ & $\begin{array}{l}\text { Posta ve kurye faaliyetleri (53) } \\
\text { Üye olunan kuruluşların faaliyetleri (94) } \\
\text { Diğer hizmet faaliyetleri (96) } \\
\text { Ev içi çalışan personelin işverenleri olarak hanehalklarının } \\
\text { faaliyetleri (97) } \\
\text { Hanehalkları tarafından kendi kullanımlarına yönelik olarak üretilen } \\
\text { ayrım yapılmamış mal ve hizmetler (98) } \\
\text { Uluslararası örgütler ve temsilciliklerinin faaliyetleri (99) }\end{array}$ \\
\hline
\end{tabular}

Kaynak: www.ec.europa.eu

Firma herhangi bir mal veya hizmetin üretim sürecinde deneyim kazandıkça, ortalama üretim maliyeti düzenli olarak azalır. Başka bir deyişle, söz konusu bir yıldaki belirli bir üretim seviyesi için, toplam üretim miktarının zamanla kümülatif olarak artması, genellikle firmanın ortalama maliyetinde önemli ölçüde azalmaya sebep olacaktır. Öğrenme veya deneyim eğrisi, firmanın kümülatif toplam üretim miktarı arttıkça ortalama maliyetteki düşüşü göstermektedir (Salvatore, 2003: 251).

Öğrenme eğrisi çeşitli fonksiyonel biçimlere sahiptir. Bu modeller Log-lineer model, Plato modeli, Stanford modeli, Dejong modeli, S modeli vb.dir. Söz konusu modeller içerisinde, Wright tarafından geliştirilen log-lineer öğrenme eğrisi modeli şimdiye kadar yaygın bir biçimde kullanılmıştır (Yelle, 1979: 304). Log-lineer model, geleneksel lineer öğrenme eğrisi varsayımı altında teknolojik ilerleme oranını tahmin etmek için kullanılmaktadır. Wright'ın geleneksel öğrenme eğrisi modelini şöyle ifade etmek mümkündür (Anzanello \& Fogliatto, 2011: 574).

$$
C_{t}=C_{1} X_{t}^{-a}
$$

$\mathrm{C}_{\mathrm{t}}$ : $\mathrm{t}$ zamanındaki üretim düzeyi başına işgücü girdisini, $\mathrm{C}_{1}$ : ilk üretim düzeyini elde etmek için gereli olan işgücü girdisini, $X_{t}$ : t zamanına kadar olan kümülatif üretim miktarını ve $-\alpha$ ise ögrenme esnekliğini temsil eder. 1 no.lu denklemin logaritmik biçimi 2 no.lu denklemle aşağıdaki gibi ifade edilebilir (Karaöz \& Albeni, 2005: 870):

$$
\ln C_{t}=\ln C_{1}+a \ln X_{t}
$$

Denklem 2'de yer alan $C_{t}$ yani $\mathrm{t}$ zamanındaki birim üretim maliyeti, kümülatif üretim seviyesini temsil eden $X_{t}$ ve üretim sürecinde ilk birimin üretim maliyetini gösteren $C_{1}$ 'in bir fonksiyonudur. Ayrıca, öğrenme etkisi ise $a$ 'nın değeri ile ölçülmektedir. $a$ 'nın değeri ne kadar büyük olursa, öğrenme etkileri de o kadar önemlidir. İlerleme oranı $(d)$ ise öğrenme esnekliğini temsil eden $a$ ile türetilmektedir. İlerleme oranı, kümülatif üretim seviyesi veya deneyim ikiye katlandığında birim başına maliyetin hangi oranda azaldığını göstermektedir. İlerleme veya öğrenme oranı, $d=2^{-a}$ formülü ile hesaplanmaktadır (Pramongkit, Shawyun, \& Sirinaovakul, 2000: 190).

Herhangi bir firma veya endüstride öğrenme söz konusu ise, ilerleme oranı değerlerinin sıfir ile bir arasında olması beklenir. İlerleme oranı değeri sıfıra yaklaştıkça daha iyi öğrenme olmaktadır. Bununla birlikte, bire yakın ilerleme oranı değeri düşük öğrenme oranını göstermektedir. Birden büyük bir ilerleme oranı ise öğrenme yerine unutma yaşandığını ifade eder. Yani, toplam üretim miktarı arttıkça birim üretim maliyetlerinde bir artış veya verimlilikte bir azalma gerçekleşmektedir. 
Ayrıca, ilerleme oranının değeri 1'e eşit olduğunda ne öğrenme ne de unutma söz konusudur (Karaöz \& Albeni, 2005: 871).

Öğrenme eğrisi etkisini hesaplamak için 3 no.lu denklemde verilen geleneksel Neo-klasik üretim fonksiyonundan faydalanabiliriz.

$$
Q_{t}=A_{t} L_{t}^{\alpha} K_{t}^{\beta}
$$

$\mathrm{Q}_{\mathrm{t}} ; \mathrm{t}$ yılındaki üretim düzeyini, $\mathrm{L}_{\mathrm{t}} ; \mathrm{t}$ yılındaki işgücü seviyesini, $\mathrm{K}_{\mathrm{t}} ; \mathrm{t}$ yılındaki sermaye düzeyini ve $A_{t}$, yılındaki teknoloji seviyesini göstermektedir. $\alpha$ ve $\beta$ sirasıyla üretimin işgücü ve sermaye esnekliğidir. $\alpha$ ve $\beta$ parametrelerinin toplamı, ölçeğe göre getiriyi ifade etmektedir. $\alpha+$ $\beta>1$ ise ölçeğe göre artan ve $\alpha+\beta<1$ ise ölçeğe göre azalan getiri vardır. $\alpha+\beta=1$ olduğu durumda ölçeğe göre sabit getiri söz konusudur (Salvatore, 2003: 221).

3 no.lu denklemin logaritmik biçimi 4 no.lu denklemdeki gibi gösterilebilir.

$$
\ln Q_{t}=\ln A_{t}+\alpha \ln L_{t}+\beta \ln K_{t}
$$

$A_{t}$ ile $X_{t}$ arasında 5 no.lu denklemde ifade edilen fonksiyonel ilişki bulunmaktadır.

$$
A_{t}=H X_{t}^{a}
$$

Bu denklemde yer alan $H$ bir sabittir ve $X_{t}^{a}$, daha önce 1 no.lu denklemde $1\left(X_{t}^{a}={ }^{C_{1}} / C_{t}\right)$ ile ifade edilen $X_{t}^{-a}$ 'nın tersidir. Denklem 5'in doğal logaritmik biçimi ise şu şekildedir:

$$
\ln A_{t}=\ln H+a \ln X_{t}
$$

$X_{t}^{a}=C_{1} C_{t}$ ilişkisini kullanarak, 5 no.lu denklemi 7 no.lu denklemdeki gibi yazabiliriz.

$$
A_{t}=H \frac{C_{1}}{C_{t}}
$$

7 no.lu denklemin logaritmik biçimi 8 no.lu denklemdeki gibidir.

$$
\ln A_{t}=\ln H+\ln \left(\frac{C_{1}}{C_{t}}\right)
$$

Kübik öğrenme modelinde öğrenme seviyesinin zaman içinde değiştiği varsayılmaktadır. Carlson (1973), kübik öğrenme oranlarını tahmin etmek için S-eğrisi fonksiyonunun kullanılması gerektiğini göstermiş̧ir. S-eğrisi fonksiyonu, t zamanında birim başına üretim maliyetinin, üçüncü dereceden polinomal bir kümülatif üretim fonksiyonu olduğunu ifade eder (Karaöz \& Albeni, 2005: 872). Bu çalışmada, öğrenme düzeyini tespit emek için kübik öğrenme modeli kullanılmıştır. Kübik öğrenme modeli 9 no.lu denklemdeki gibi gösterilebilir.

$$
\ln C_{t}=\ln C_{1}+B \ln X_{t}+C\left(\ln X_{t}\right)^{2}+D\left(\ln X_{t}\right)^{3}
$$

9 no.lu eşitlikte $t$ yılındaki üretimin birim başına maliyeti kümülatif üretim seviyesinin bir fonksiyonudur. Öğrenme esnekliği, 9 no.lu denklemin birinci dereceden türevi ile belirlenmektedir.

$$
-a=\frac{d \ln C_{t}}{d \ln X_{t}}=B+2 C \ln X_{t}+3 D\left(\ln X_{t}\right)^{2}
$$

11 no.lu denklem, 9 no.lu denklemden aşağıdaki gibi elde edilebilir:

$$
\ln \left(\frac{C_{1}}{C_{t}}\right)=-\left[B \ln X_{t}+C\left(\ln X_{t}\right)^{2}+D\left(\ln X_{t}\right)^{3}\right]
$$

8 no.lu denklemde yer alan $\ln \left(\frac{C_{1}}{C_{t}}\right)$ ifadesi yerine 11 no.lu denklemdeki eşitliğini ilave edersek 12 no.lu denklemi elde ederiz.

$$
\ln A_{t}=\ln H-B \ln X_{t}-C\left(\ln X_{t}\right)^{2}-D\left(\ln X_{t}\right)^{3}
$$

12 no.lu denklemi, 4 no.lu denkleme eklediğimizde ise 13 no.lu denklem bulunur.

$$
\ln Q_{t}=\ln H-B \ln X_{t}-C\left(\ln X_{t}\right)^{2}-D\left(\ln X_{t}\right)^{3}+\alpha \ln L_{t}+\beta \ln K_{t}
$$


13 no.lu denklemde, sermaye ve emek arasındaki ilişkinin şöyle olduğu varsayılmaktadır:

$$
K_{t}=\mu L_{t}^{\lambda}
$$

$\mu$ ve $\lambda$ sabittir. $\mathrm{Bu}$ denklemin logaritmik biçimi 13 no.lu denkleme eklenerek 15 no.lu denkleme ulaşabiliriz.

$$
\ln Q_{t}=\ln H-B \ln X_{t}-C\left(\ln X_{t}\right)^{2}-D\left(\ln X_{t}\right)^{3}+\alpha \ln L_{t}+\beta\left(\ln \mu+\lambda \ln L_{t}\right)
$$

15 no.lu denklemin her iki tarafina $\ln L_{t}$ eklendikten sonra 16 no.lu denklem elde edilir.

$$
\ln (L / Q)_{t}=-\ln H-\beta \ln \mu+B \ln X_{t}+C\left(\ln X_{t}\right)^{2}+D\left(\ln X_{t}\right)^{3}+(1-\beta \lambda-\alpha) \ln L_{t}
$$

16 no.lu denklemi daha kolay bir biçimde ifade edebilmek için $\theta_{1}=-(\ln H+\beta \ln \mu), \theta_{2}=$ $(1-\beta \lambda-\alpha) \ln L_{t}$ ve $\ln C_{t}=\ln (L / Q)_{t}$ olduğunu varsayarsak 17 no.lu denkleme ulaşabiliriz (Karaöz \& Albeni, 2005: 875).

$$
\ln C_{t}=\theta_{1}+B \ln X_{t}+C\left(\ln X_{t}\right)^{2}+D\left(\ln X_{t}\right)^{3}+\theta_{2} \ln L_{t}
$$

17 no.lu denklemin birinci dereceden türevi 18 no.lu denklemle gösterilen öğrenme esnekliğini vermektedir.

$$
-a=\frac{\partial C_{t}}{\partial X_{t}} \frac{X_{t}}{C_{t}}=B+2 C \ln X_{t}+3 D\left(\ln X_{t}\right)^{2}
$$

\section{AMPIRIKK BULGULAR}

17 no.lu denklemde yer alan $\theta_{1}, \theta_{2}, \mathrm{~B}, \mathrm{C}$ ve $\mathrm{D}$ parametrelerini tahmin etmek için En Küçük

\begin{tabular}{|c|c|c|c|c|c|c|c|c|}
\hline & Kod & $\theta_{1}$ & $\theta_{2}$ & B & C & D & $F$ değeri & $R^{2}$ \\
\hline \multirow{9}{*}{$\begin{array}{l}\text { Yüksek } \\
\text { Teknoloji } \\
\text { ve Finansal } \\
\text { Hizmetleri } \\
\text { İçeren Bilgi } \\
\text { Yoğun } \\
\text { Piyasa } \\
\text { Hizmetleri }\end{array}$} & 50 & $\begin{array}{l}1079,357 \\
(2,22)^{* * *}\end{array}$ & $\begin{array}{l}0,211 \\
(0,58)\end{array}$ & $\begin{array}{l}-170,421 \\
(-2,19)^{* * *}\end{array}$ & $\begin{array}{c}8,908 \\
(2,15)^{* * *}\end{array}$ & $\begin{array}{c}-0,155 \\
(-2,13)^{* * *}\end{array}$ & $3,36^{* * *}$ & 0,573 \\
\hline & 51 & $\begin{array}{c}256,926 \\
(1,10)\end{array}$ & $\begin{array}{c}1,345 \\
(4,57)^{*}\end{array}$ & $\begin{array}{c}-46,859 \\
(-1,31)\end{array}$ & $\begin{array}{l}2,622 \\
(1,42)\end{array}$ & $\begin{array}{l}-0,049 \\
(-1,55)\end{array}$ & $11,16^{*}$ & 0,817 \\
\hline & 69 & $\begin{array}{l}-537,465 \\
(-2,88)^{* *}\end{array}$ & $\begin{array}{l}-0,371 \\
(-0,70)\end{array}$ & $\begin{array}{l}89,253 \\
(2,90)^{* *}\end{array}$ & $\begin{array}{c}-4,903 \\
(-2,94)^{* *}\end{array}$ & $\begin{array}{c}0,090 \\
(2,97)^{* *}\end{array}$ & $6,27^{*}$ & 0,715 \\
\hline & 70 & $\begin{array}{c}361,483 \\
(0,59)\end{array}$ & $\begin{array}{c}1,244 \\
(1,95)^{* * *}\end{array}$ & $\begin{array}{c}-49,088 \\
(-0,61) \\
\end{array}$ & $\begin{array}{l}2,089 \\
(0,59) \\
\end{array}$ & $\begin{array}{l}-0,030 \\
(-0,59) \\
\end{array}$ & $3,25^{* * *}$ & 0,565 \\
\hline & 71 & $\begin{array}{c}-168,290 \\
(-1,64) \\
\end{array}$ & $\begin{array}{c}0,667 \\
(1,86)^{* * *}\end{array}$ & $\begin{array}{c}26,264 \\
(1,60) \\
\end{array}$ & $\begin{array}{l}-1,445 \\
(-1,64) \\
\end{array}$ & $\begin{array}{l}0,026 \\
(1,66)\end{array}$ & $4,72^{* *}$ & 0,654 \\
\hline & 73 & $\begin{array}{c}937,330 \\
(4,39)^{*}\end{array}$ & $\begin{array}{l}-0,382 \\
(-1,12)\end{array}$ & $\begin{array}{c}-146,575 \\
(-4,36)^{*}\end{array}$ & $\begin{array}{c}7,630 \\
(4,31)^{*}\end{array}$ & $\begin{array}{c}-0,132 \\
(-4,26)^{*}\end{array}$ & $25,18^{*}$ & 0,910 \\
\hline & 74 & $\begin{array}{c}-43,319 \\
(-0,23)\end{array}$ & $\begin{array}{l}-0,118 \\
(-0,60)\end{array}$ & $\begin{array}{l}9,856 \\
(0,30)\end{array}$ & $\begin{array}{l}-0,715 \\
(-0,36)\end{array}$ & $\begin{array}{l}0,017 \\
(0,43)\end{array}$ & $4,58^{* *}$ & 0,650 \\
\hline & 78 & $\begin{array}{c}-35,746 \\
(-0,31) \\
\end{array}$ & $\begin{array}{l}0,184 \\
(0,98)\end{array}$ & $\begin{array}{l}5,098 \\
(0,24)\end{array}$ & $\begin{array}{l}-0,260 \\
(-0,21)\end{array}$ & $\begin{array}{l}0,004 \\
(0,18)\end{array}$ & $2,65^{* * *}$ & 0,515 \\
\hline & 80 & $\begin{array}{l}34,310 \\
(2,27)^{* *}\end{array}$ & $\begin{array}{l}0,083 \\
(0,72)\end{array}$ & $\begin{array}{c}-6,483 \\
(-2,55)^{* *}\end{array}$ & $\begin{array}{c}0,387 \\
(2,58)^{* *}\end{array}$ & $\begin{array}{c}-0,008 \\
(-2,64)^{* *}\end{array}$ & $67,13^{*}$ & 0,964 \\
\hline \multirow{2}{*}{$\begin{array}{l}\text { Diğer Bilgi } \\
\text { Yoğun } \\
\text { Hizmetler }\end{array}$} & 58 & $\begin{array}{c}26,068 \\
(0,33)\end{array}$ & $\begin{array}{c}0,940 \\
(3,05)^{* *}\end{array}$ & $\begin{array}{l}-5,672 \\
(-0,43)\end{array}$ & $\begin{array}{l}0,249 \\
(0,33)\end{array}$ & $\begin{array}{l}-0,004 \\
(-0,25)\end{array}$ & $81,30^{*}$ & 0,970 \\
\hline & 75 & $\begin{array}{l}-462,314 \\
(-1,93)^{* * *}\end{array}$ & $\begin{array}{c}0,936 \\
(3,14)^{* *}\end{array}$ & $\begin{array}{c}86,742 \\
(1,89)^{* * *}\end{array}$ & $\begin{array}{c}-5,537 \\
(-1,88)^{* * *}\end{array}$ & $\begin{array}{c}0,117 \\
(1,86)^{* * *}\end{array}$ & $9,17^{*}$ & 0,786 \\
\hline
\end{tabular}
Kareler yöntemi kullanılmıştır. İlgili parametreler aracılığıyla öğrenme esnekliğini ifade eden $a$ değeri hesaplanmış ve ilerleme veya öğrenme oranını tespit etmek için ise $d=2^{-a}$ formülünden yararlanılmıştır.

Tablo 3: Kübik Modelden Elde Edilen Tahmin Sonuçları 


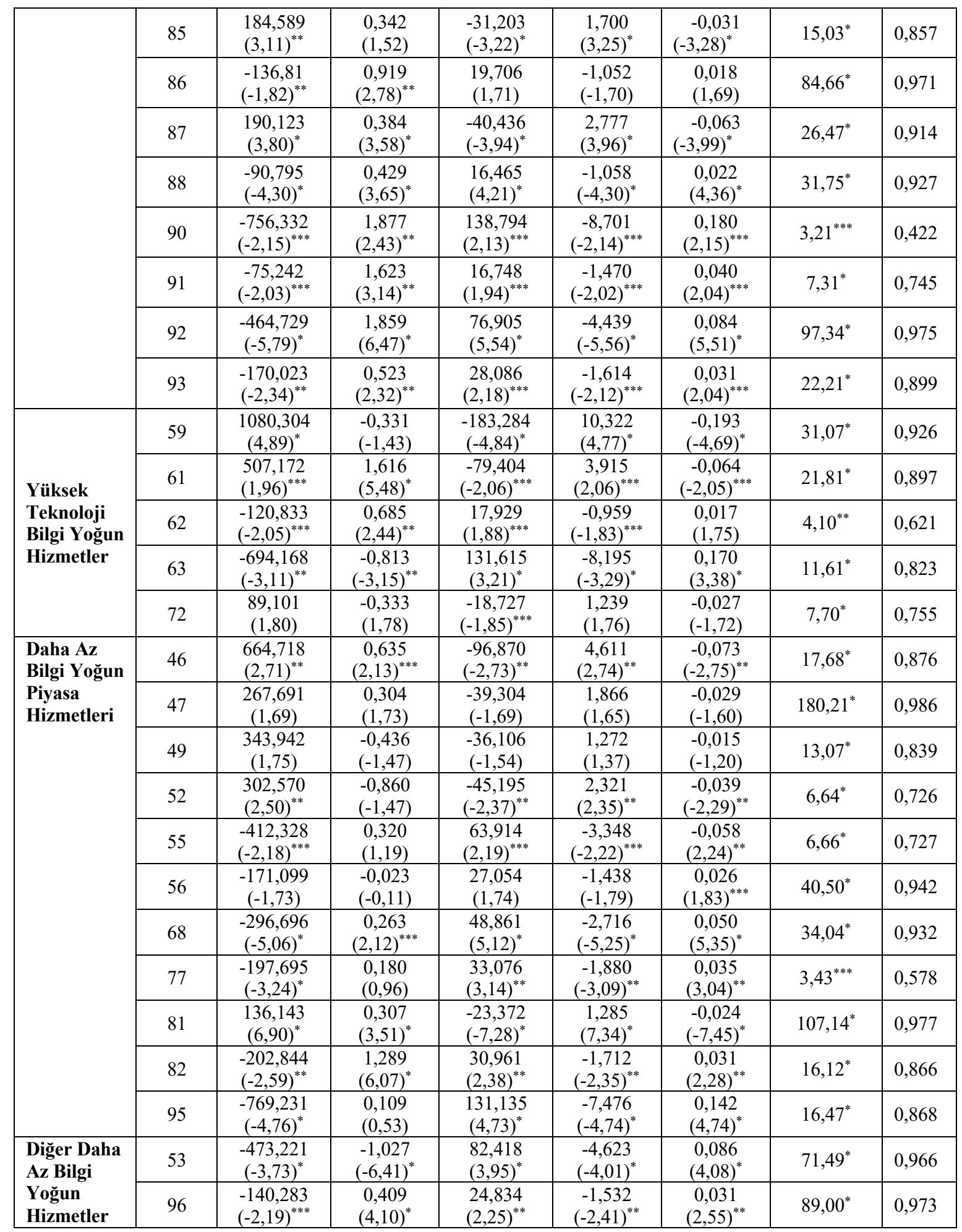

${ }^{* * *}{ }^{*}$ ve ${ }^{* * *}$ sirasıyla $\% 1, \% 5$ ve $\% 10$ önem düzeyinde istatistiki açıdan anlamlılığı temsil etmektedir.

Tablo 3’te, 2002-2017 dönemi itibariyle Bilgi Yoğun Hizmetler alt sektörleri için kübik öğrenme modeli kullanılarak tahmin edilen katsayılar görülmektedir. Tablo 3 'te yer alan tüm modeller, ilgili önem düzeyinde (F değerleri) bir bütün olarak istatistiksel olarak anlamlıdır. Modellerin $\mathrm{R}^{2}$ değerleri \%42,2 ile \%98,6 arasında değişim göstermektedir. Parametreler için hesaplanan $t$ değerleri alt sektörlerin birçoğu için ilgili katsayının istatistiki açıdan seçilen önem düzeyinde $(\% 1, \% 5$ ve \%10) anlamlı olduğunu belirtmektedir. 
Bilgi Yoğun Hizmetler alt sektörleri için öğrenme seviyesi (ilerleme oranı) değerleri, Tablo 4'te sunulmaktadır. Bu değerler, $d=2^{-a}$ formülünden hareketle hesaplanmıştır. Tablo 4'te yer alan öğrenme seviyesi değerleri incelendiğinde, 1 değerinin altındaki bir öğrenme seviyesi, öğrenmenin hala devam ettiğini gösterirken, 1 değerinin üzerindeki öğrenme seviyesi ise unutmayı ifade etmektedir. Şayet öğrenme seviyesi değeri 1'e eşit ise verimliliğin değişmemekte ve bir gelişme veya kötüleşme bulunmamaktadır. Gölgelendirilmiş hücreler 1 değerinin üzerindeki teknolojik öğrenme seviyesini yani, unutkanlık durumunu ifade ederken, gölgesiz hücreler ise ilgili alt sektör tarafından üretim sürecinde yaşanan verimlilik kazancını veya öğrenme durumunu göstermektedir.

Tablo 4: 2003-2017 Dönemi İtibariyle Bilgi Yoğun Hizmetler Alt Sektörlerinde Yıllık Öğrenme Seviyesi

\begin{tabular}{|c|c|c|c|c|c|c|c|c|c|c|c|c|c|c|c|c|}
\hline $\begin{array}{c}\text { Yil } \\
\text { Kod }\end{array}$ & 2003 & 2004 & 2005 & 2006 & 2007 & 2008 & 2009 & 2010 & 2011 & 2012 & 2013 & 2014 & 2015 & 2016 & 2017 & Ort. \\
\hline 46 & 0,742 & 0,965 & 1,030 & 1,031 & 1,008 & 0,978 & 0,947 & 0,912 & 0,875 & 0,838 & 0,800 & 0,763 & 0,727 & 0,692 & 0,656 & 0,864 \\
\hline 47 & 907 & 048 & 104 & 126 & 1,136 & 1,136 & 133 & 1,127 & 1,119 & 1,110 & 1,099 & 1,088 & 1,076 & 1,063 & 1,050 & 1,088 \\
\hline 49 & 713 & 894 & 038 & 1,145 & 1,220 & 1,276 & 1,314 & 1,350 & 1,385 & 1,417 & 1,445 & 1,470 & 1,492 & & 1,531 & 1,280 \\
\hline 50 & 470 & 013 & 1,174 & 1,213 & 1,207 & 1,172 & 1,144 & 1,107 & 1,063 & 1,018 & 0,976 & 0,933 & 0,892 & 0,855 & 0,813 & 1,003 \\
\hline 51 & 0,905 & 891 & 0,838 & 0,778 & 0,723 & 0,671 & 0,623 & 0,578 & 0,531 & 0,487 & 0,447 & 0,407 & 0,373 & 0,346 & 0,295 & 0,593 \\
\hline 52 & 0,991 & 1,317 & 1,450 & 1,488 & 1,504 & 1,505 & 1,496 & 1,478 & 1,454 & 1,426 & 1,394 & 1,360 & 1,325 & 1,292 & 1,254 & 1,382 \\
\hline 53 & 1,242 & ,934 & 0,892 & 0,878 & 0,876 & 0,885 & 0,917 & 0,964 & 1,023 & 1,093 & 1,172 & & 1,345 & 1,440 & 1,536 & 1,097 \\
\hline 55 & 1,210 & 980 & 0,903 & 0,882 & 0,883 & 0,898 & 0,921 & 0,952 & 0,992 & 1,034 & 1,083 & & 1,190 & 1,229 & 1,278 & 1,038 \\
\hline 56 & 071 & & 1,023 & 1,039 & 1,060 & 1,086 & 1,116 & & 1,186 & 1,225 & 1,265 & & 1,349 & 1,392 & 1,437 & 182 \\
\hline 58 & 768 & & 883 & 0,908 & 0,9 & 0,927 & 0,952 & & & 0,982 & 0,989 & & 000 & 005 & 1,010 & \\
\hline 59 & 347 & & 952 & 2,034 & 2,040 & 2,016 & 1,946 & 342 & 1,716 & 1,5 & 1,438 & & & & 955 & 538 \\
\hline 61 & 0,765 & 978 & 1,037 & 1,056 & 1,053 & 1,041 & 1,022 & 1,001 & 0,978 & 0,954 & 0,930 &, 907 & 0,885 & 0,862 & 840 & 954 \\
\hline 62 & 1,008 & 861 & 802 & 0,766 & 0,746 & 0,731 & 0,720 & 0,714 & 0,712 & 0,711 & 0,713 & 0,716 & 720 &, 726 &, 732 & 0,759 \\
\hline 63 & 1,596 & 29 & 943 & 1,016 & 1,281 & 1,620 & 1,787 & 1,991 & 2,236 & 2,490 & 2,758 & 3,084 & 509 & 012 & 4,627 & 2,265 \\
\hline 68 & 1,081 & 0,824 & 0,760 & 0,743 & 0,748 & 0,762 & 0,808 & 0,860 & 0,922 & 0,994 & 1,072 & 1,154 & 1,233 & 1,312 & 1,396 & 0,978 \\
\hline 69 & 1,491 & 1,082 & 1,024 & 1,012 & 1,043 & 1,096 & 1,179 & 1,274 & 1,379 & 1,493 & 1,614 & 1,744 & 1,885 & 2,036 & 2,182 & 1,436 \\
\hline 70 & 0,490 & 0,604 & 0,656 & 0,678 & 0,678 & 0,654 & 0,633 & 0,621 & 0,607 & 0,592 & 0,577 & 0,560 & 0,541 & 0,522 & 0,501 & 0,594 \\
\hline 71 & 0,922 & 0,802 & 0,755 & 0,727 & 0,721 & 0,724 & 0,735 & 0,750 & 0,769 & 0,789 & 0,811 & 0,835 & 0,861 & 0,887 & 0,917 & 0,800 \\
\hline 72 & 0,474 & 0,644 & 0,760 & 0,946 & 0,982 & 0,986 & 0,982 & 0,963 & 0,935 & 0,904 & 0,865 & 0,827 & 0,800 & 0,767 & 0,735 & 0,838 \\
\hline 73 & & & & 1,6 & & & & & & 20 & 1,241 & & & 1,030 & 0,968 & 1,306 \\
\hline 74 & 0,820 & 0,892 & 0,949 & 1,039 & 1,112 & 1,174 & 1,204 & 1,241 & 1,280 & 1,325 & 1,379 & 1,444 & 510 & 1,578 & 1,650 & 1,240 \\
\hline 75 & 1,784 & & & 0,703 & 0,636 & & 0,591 & & & 0,628 & 0,661 & 0,704 & & 0,817 & 0,891 & 0,794 \\
\hline 77 & 1,349 & 087 & 961 & 0,907 & 0,88 & 0,868 & 0,860 & 863 & 0,87 & 0,894 & 0,919 & 1 & 988 & 1,028 & 1,075 &, 967 \\
\hline 78 & 0,928 & & 863 & 0,844 & 0,8 & & 0,82 & & & 0,807 & 0,802 & 0,797 & 792 & 0,789 & 0,784 & 828 \\
\hline 80 & 0,958 & 005 & 1,022 & 1,028 & 1,027 & 1,021 & 1,013 & 1,004 & 0,994 & 0,983 & 0,972 & 0,960 & 0,948 & 0,936 & 0,924 & 0,986 \\
\hline 81 & 0,805 & 926 & 0,974 & 0,984 & 0,980 & 0,969 & 0,952 & 0,933 & 0,912 & 0,889 & 0,864 & 0,839 & 0,813 & 0,786 & 0,760 & 0,892 \\
\hline 82 & 0,906 & 0,703 & 0,629 & 0,588 & 0,571 & 0,559 & 0,553 & 0,553 & 0,557 & 0,564 & 0,573 & & 0,595 & 0,609 & 0,623 & 0,611 \\
\hline 85 & 0,857 & 0,962 & 0,992 & 0,993 & 0,983 & 0,968 & 0,950 & 0,929 & 0,908 & 0,886 & 0,861 & 0,836 & 0,811 & 0,786 & 0,763 & 0,899 \\
\hline 86 & 0,888 & 0,796 & 0,763 & 0,750 & 0,746 & 0,747 & 0,752 & 0,758 & 0,766 & 0,775 & 0,785 & 0,795 & 0,806 & 0,817 & 0,827 & 0,785 \\
\hline 87 & 0,655 & 0,943 & 1,033 & 1,052 & 1,050 & 1,038 & 1,015 & 0,981 & 0,937 & 0,891 & 0,839 & 0,792 & 0,743 & 0,691 & 0,636 & 0,886 \\
\hline 88 & 1,009 & 0,881 & 0,839 & 0,825 & 0,823 & 0,831 & 0,847 & 0,867 & & 0,913 & 0,939 & & 0,988 & 1,016 & 1,044 & 0,912 \\
\hline 90 & 1,681 & 0,770 & 0,550 & 0,439 & 0,393 & 0,392 & 0,416 & 0,465 & 0,534 & 0,621 & 0,739 & & 1,074 & 1,131 & 1,366 & 0,764 \\
\hline 91 & 0,782 & & 0,428 & & & 0,370 & 0,390 & & & 0,506 & 0,576 & & 0,727 & 0,769 & 0,855 & 0,548 \\
\hline 92 & 1,521 & 0,801 & 0,603 & 0,495 & 0,454 & 0,436 & 0,434 & 0,479 & 0,542 & 0,620 & 0,706 & 0,800 & 0,896 & 0,995 & 1,097 & 0,725 \\
\hline 93 & 1,244 & 0,996 & & 0,865 & & & & & & & & & & & 0,883 & 0,879 \\
\hline 95 & 1,779 & 1,138 & 0,968 & 0,912 & 0,906 & & 0,970 & 1,035 & & 1,213 & 1,301 & & 1,492 & 1,603 & 1,726 & 1,232 \\
\hline 96 & 0,906 & 0,850 & 0,854 & 0,875 & 0,905 & 0,937 & 0,981 & 1,031 & 1,081 & 1,129 & 1,173 & 1,214 & 1,258 & 1,301 & 1,346 & 1,056 \\
\hline
\end{tabular}

Tablo 4'teki y1llık öğrenme seviyesi değerleri, ilgili alt sektör için kümülatif üretimin iki katına çıkması durumunda birim üretim maliyetlerinde yaşanan düşüş veya artışları göstermektedir. Yı1lık öğrenme seviyelerinin bir yıldan diğerine değişmesi, teknolojik öğrenme seviyesinin her yıl için farklılık sergilediğini ifade etmektedir. Örneğin, 46 kodlu Toptan ticaret (Motorlu kara taşıtları ve motosikletler hariç) alt sektörü için 2003, 2004 ve 2005 ylllarında, yıllık teknolojik öğrenme seviyeleri sırasıyla $0.742,0,965$ ve 1.030 'dur. Bu sayılar, belirli bir yıl için elde edilen veya kaçırılan birim başına maliyet verimliliğini gösterir. Örneğin, 2003 ve 2004'te, Toptan ticaret (Motorlu kara taşıtları ve motosikletler hariç) alt sektörü üretimi için birim üretim maliyetleri, üretim düzeyinin her iki katına çıkması ile birlikte $\% 25,8$ ve $\% 3,5$ oranında azalırken, 2005 yılında birim üretim maliyeti $\% 3$ oranında artmıştır. Bu sayı (1.030), ilgili alt sektör için 2005 yılında unutmanın gerçekleştiğini ifade etmektedir.

Tablo 5, 2003-2017 dönemi itibariyle Bilgi Yoğun Hizmetler alt sektörleri için Tablo 4'teki her bir alt sektörün öğrenme seviyesini belirten rakamlardan türetilen öğrenme eğrilerini göstermektedir. Söz konusu alt sektörler, öğrenme eğrilerinin şekillerinin benzerliğine bağlı olarak dört kategoride toplanmıştır. Bu kategoriler; bir minimum noktasına sahip olan dışbükey öğrenme 
eğrisi, bir maksimum noktasına sahip olan içbükey öğrenme eğrisi, bir minimum noktası olmayan negatif eğimli öğrenme eğrisi ve bir maksimum noktası olmayan pozitif eğimli öğrenme eğrisi şeklindedir. Alt kategoriler ise ilgili alt sektörde unutmanın yaşanıp yaşanmamasına bağlı olarak iki sınıfa ayrılmıştır.

Tablo 5: 2003-2017 Dönemi İtibariyle Bilgi Yoğun Hizmetler Alt Sektörleri Öğrenme Eğrileri

\begin{tabular}{|c|c|c|c|}
\hline \multicolumn{2}{|c|}{ Öğrenme Eğrisinin Şekli } & \multirow[b]{2}{*}{$\begin{array}{l}\text { Unutma } \\
\text { Baz1 } \\
\text { Y1llarda } \\
\text { Unutma }\end{array}$} & \multirow[b]{2}{*}{$\begin{array}{l}\text { Alt Sektör } \\
\text { Posta ve kurye faaliyetleri, Konaklama, Yiyecek ve içecek } \\
\text { hizmeti faaliyetleri, Bilgisayar programlama, danışmanlık ve } \\
\text { ilgili faaliyetler, Bilgi hizmet faaliyetleri, Gayrimenkul } \\
\text { faaliyetleri, Hukuk ve muhasebe faaliyetleri, Veterinerlik } \\
\text { hizmetleri, Kiralama ve leasing faaliyetleri, Barınacak yer } \\
\text { sağlanmaksızın verilen sosyal hizmetler, Yaratıcı sanatlar, } \\
\text { gösteri sanatları ve eğlence faaliyetleri, Kumar ve müşterek } \\
\text { bahis faaliyetleri, Spor faaliyetleri, eğlence ve dinlence } \\
\text { faaliyetleri, Bilgisayarların, kişisel eşyaların ve ev eşyalarının } \\
\text { onarımı, Diğer hizmet faaliyetleri }\end{array}$} \\
\hline \multirow[t]{2}{*}{$\begin{array}{l}\text { Bir } \\
\text { Minimum } \\
\text { Noktasına } \\
\text { Sahip } \\
\text { Dişbükey } \\
\text { Öğrenme } \\
\text { Eğrisi }\end{array}$} & \multirow[t]{2}{*}{$\backslash$} & & \\
\hline & & $\begin{array}{l}\text { Hiçbir } \\
\text { Y1lda } \\
\text { Unutmama }\end{array}$ & $\begin{array}{l}\text { Mimarlık ve mühendislik faaliyetleri; teknik muayene ve analiz, } \\
\text { Büro yönetimi, büro destek ve iş destek faaliyetleri, İnsan } \\
\text { sağlı̆̆ hizmetleri, Kütüphaneler, arşivler, müzeler ve diğer } \\
\text { külttürel faaliyetler }\end{array}$ \\
\hline \multirow[t]{2}{*}{$\begin{array}{l}\text { Bir } \\
\text { Maksimum } \\
\text { Noktasına } \\
\text { Sahip } \\
\text { İçbükey } \\
\text { Öğrenme } \\
\text { Eğrisi }\end{array}$} & & $\begin{array}{l}\text { Baz1 } \\
\text { Y1llarda } \\
\text { Unutma }\end{array}$ & $\begin{array}{l}\text { Toptan ticaret (Motorlu kara taşıtları ve motosikletler hariç), } \\
\text { Perakende ticaret (Motorlu kara taşıtları ve motosikletler hariç), } \\
\text { Su yolu taşımacılığı, Taşımacılık için depolama ve destekleyici } \\
\text { faaliyetler, Sinema filmi, video ve televizyon programları çekim } \\
\text { sonrası faaliyetleri, Telekomünikasyon, Reklamcılık ve piyasa } \\
\text { araştırması, Güvenlik ve soruşturma faaliyetleri, Yatılı bakım } \\
\text { faaliyetleri }\end{array}$ \\
\hline & & $\begin{array}{l}\text { Hiçbir } \\
\text { Y1lda } \\
\text { Unutmama }\end{array}$ & $\begin{array}{l}\text { İdare merkezi faaliyetleri; idari danışmanlık faaliyetleri, } \\
\text { Bilimsel araştırma ve geliştirme faaliyetleri, Binalar ile ilgili } \\
\text { hizmetler ve çevre düzenlemesi faaliyetleri, Eğitim }\end{array}$ \\
\hline \multirow{2}{*}{$\begin{array}{c}\text { Bir } \\
\text { Minimum } \\
\text { Noktası } \\
\text { Olmayan } \\
\text { Negatif } \\
\text { Eğimli } \\
\text { Öğrenme } \\
\text { Eğrisi }\end{array}$} & & $\begin{array}{l}\text { Baz1 } \\
\text { Y1llarda } \\
\text { Unutma }\end{array}$ & - \\
\hline & & $\begin{array}{l}\text { Hiçbir } \\
\text { Y1lda } \\
\text { Unutmama }\end{array}$ & Hava yolu taşımacılığı, İstihdam faaliyetleri, \\
\hline \multirow{2}{*}{$\begin{array}{c}\text { Bir } \\
\text { Maksimum } \\
\text { Noktası } \\
\text { Olmayan } \\
\text { Pozitif } \\
\text { Eğimli } \\
\text { Öğrenme } \\
\text { Eğrisi }\end{array}$} & & $\begin{array}{l}\text { Bazı } \\
\text { Yillarda } \\
\text { Unutma }\end{array}$ & $\begin{array}{l}\text { Kara taşımacıllı̆̆ ve boru hattı taşımacılığı, Yayımcılık } \\
\text { faaliyetleri, Diğer mesleki, bilimsel ve teknik faaliyetler }\end{array}$ \\
\hline & & $\begin{array}{l}\text { Hiçbir } \\
\text { Y1lda } \\
\text { Unutmama }\end{array}$ & - \\
\hline
\end{tabular}

Tablo 5'te yer alan ilk kategoride, dışbükey öğrenme eğrilerine sahip olan alt sektörler yer almaktadır. Bu şekle sahip olan alt sektörlerde öğrenme seviyesi değerleri belirli bir yıla kadar sürekli bir biçimde azalmakta ve söz konusu yıldan sonra ise ilgili değerlerde artış gözlenmektedir.

$\mathrm{Bu}$ kategorinin ilk sınıfında, 15 yıllık zaman dilimi içerisinde bazı yıllarda unutmanın gerçekleştiği yani öğrenme seviyesi değerinin 1'den büyük olduğu alt sektörler bulunmaktadır. Bu alt sektörler: Posta ve kurye faaliyetleri, Konaklama, Yiyecek ve içecek hizmeti faaliyetleri, Bilgisayar programlama, danışmanlık ve ilgili faaliyetler, Bilgi hizmet faaliyetleri, Gayrimenkul 
faaliyetleri, Hukuk ve muhasebe faaliyetleri, Veterinerlik hizmetleri, Kiralama ve leasing faaliyetleri, Barınacak yer sağlanmaksızın verilen sosyal hizmetler, Yaratııı sanatlar, gösteri sanatları ve eğlence faaliyetleri, Kumar ve müşterek bahis faaliyetleri, Spor faaliyetleri, eğlence ve dinlence faaliyetleri, Bilgisayarların, kişisel eşyaların ve ev eşyalarının onarımı ile Diğer hizmet faaliyetleri alt sektörleridir. Söz konusu kategorinin ikinci sınıfında ise 2003-2017 dönemi itibariyle hiçbir yılda unutmanın olmadığı veya her yıl için öğrenmenin gözlendiği alt sektörler ifade edilmiştir. Bu sınıfın alt sektörleri: Mimarlık ve mühendislik faaliyetleri; teknik muayene ve analiz, Büro yönetimi, büro destek ve iş destek faaliyetleri, İnsan sağlığı hizmetleri, Kütüphaneler, arşivler ile müzeler ve diğer kültürel faaliyetler alt sektörleridir.

Benzer şekilde, ikinci kategoride, öğrenme eğrisinin içbükey şeklinde olduğu alt sektörler sıralanmıştır. Bu alt sektörlerde öğrenme seviyesi değerleri belirli bir yıla kadar sürekli artmakta ve daha sonra ise ilgili değerler azalmaktadır. Bu kategorinin ilk sınıfında, ilgili dönemde öğrenme seviyesi değerinin 1'den büyük olduğu alt sektörler bulunmaktadır. Bu alt sektörler: Toptan ticaret (Motorlu kara taşıtları ve motosikletler hariç), Perakende ticaret (Motorlu kara taşıtları ve motosikletler hariç), Su yolu taşımacılığı, Taşımacılık için depolama ve destekleyici faaliyetler, Sinema filmi, video ve televizyon programları çekim sonrası faaliyetleri, Telekomünikasyon, Reklamcılık ve piyasa araştırması, Güvenlik ve soruşturma faaliyetleri ile Yatılı bakım faaliyetleri alt sektörleridir. Kategorinin ikinci sınıfında ise hiçbir yılda unutmanın olmadığ 1 alt sektörler bulunmaktadır. Bu sınıfın alt sektörleri: İdare merkezi faaliyetleri; idari danışmanlık faaliyetleri, Bilimsel araştırma ve geliştirme faaliyetleri, Binalar ile ilgili hizmetler ve çevre düzenlemesi faaliyetleri ile Eğitim alt sektörleridir.

Ayrıca, üçüncü kategori, negatif eğimli öğrenme eğrilerine sahip olan alt sektörleri göstermektedir. $\mathrm{Bu}$ alt sektörlerde öğrenme seviyesi değerleri ilgili dönem itibariyle daima azalmaktadır. Bu kategoride hiçbir yılda unutmanın olmadığı Hava yolu taşımacılı̆̆ 1 ile İstihdam faaliyetleri alt sektörleri yer almaktadır.

Son olarak, dördüncü kategori, öğrenme eğrisinin pozitif eğimli olduğu yani öğrenme seviyesi değerlerinin 2003-2017 zaman diliminde sürekli olarak arttığı alt sektörleri kapsamaktadır. İlgili kategori, bazı y1llarda unutmanın yaşandığı Kara taşımacılı̆̆ faaliyetleri ile Diğer mesleki, bilimsel ve teknik faaliyetler alt sektörleri'nden oluşmaktadır.

Yüksek teknoloji ve finansal hizmetleri içeren bilgi yoğun piyasa hizmetleri kategorisinde yer alan alt sektörlerin öğrenme eğrilerinin şekilleri farklılıklar arz etmektedir. Su yolu taşımacılığı İdare merkezi faaliyetleri; idari danışmanlık faaliyetleri, Reklamcılık ve piyasa araştırması ile Güvenlik ve soruşturma faaliyetleri alt sektörlerinin öğrenme eğrilerinin şekli içbükeydir. Hava yolu taşımacıllı̆ı ile istihdam faaliyetleri alt sektörlerinin öğrenme eğrilerinin eğimi negatif iken Diğer mesleki, bilimsel ve teknik faaliyetler alt sektörünün öğrenme eğrisinin eğimi pozitiftir. Ayrıca, Hukuk ve muhasebe faaliyetleri ile Mimarlık ve mühendislik faaliyetleri; teknik muayene ve analiz alt sektörlerinin öğrenme eğrileri ise dışbükeydir. 51 kodlu Hava yolu taşımacıllı̆̆ merkezi faaliyetleri; idari danışmanlık faaliyetleri, 71 kodlu Mimarlık ve mühendislik faaliyetleri; teknik muayene ve analiz ile 78 kodlu İstihdam faaliyetleri alt sektörlerinde 2003-2017 döneminde her y1l öğrenme yaşanmışken 69 kodlu Hukuk ve muhasebe faaliyetleri alt sektöründe ise tüm yılarda unutma gözlenmiştir. Yüksek teknoloji ve finansal hizmetleri içeren bilgi yoğun piyasa hizmetleri kategorisinde yer alan alt sektörlerin 2003-2017 dönemi itibariyle ortalama öğrenme oranları incelendiğinde, en yüksek öğrenme düzeyinin 0,593 ile Hava yolu taşımacılığ alt sektöründe gerçekleştiği tespit edilmiştir.

Diğer bilgi yoğun hizmetler kategorisinde bulunan alt sektörlerden Eğitim, Yatılı bakım faaliyetleri ile Yayımc1lık faaliyetleri haricinde geriye kalan tüm alt sektörlerin öğrenme eğrileri dışbükey bir biçime sahiptir. Yani, genel anlamda ilgili kategoride yer alan alt sektörler belirli bir yıla kadar öğrenme yaşanmışken söz konusu yıldan sonra unutma durumu gerçekleşmiştir. 20032017 döneminde ortalama öğrenme düzeyleri incelendiğinde, diğer bilgi yoğun hizmetler kategorisinde yer alan tüm alt sektörlerde öğrenme yaşandığı görülmektedir. En büyük öğrenme düzeyinin ise 0,548 ile Kütüphaneler, arşivler, müzeler ve diğer kültürel faaliyetler alt sektöründe olduğu belirlenmiştir. 
Daha az bilgi yoğun piyasa hizmetleri kategorisinde değerlendirilen alt sektörlerin de öğrenme eğrilerinin biçimleri birbirinden farklıdır. Toptan ticaret (Motorlu kara taşıtları ve motosikletler hariç), Perakende ticaret (Motorlu kara taşıtları ve motosikletler hariç), Taşımacılık için depolama ve destekleyici faaliyetler ile Binalar ile ilgili hizmetler ve çevre düzenlemesi faaliyetleri alt sektörlerinin öğrenme eğrileri içbükeydir. Kara taşımacıllı̆̆ ve boru hattı taşımacıllığı alt sektörünün öğrenme eğrisinin şekli pozitif eğimli iken geriye kalan Konaklama, Yiyecek ve içecek hizmeti faaliyetleri, Gayrimenkul faaliyetleri, Kiralama ve leasing faaliyetleri, Büro yönetimi, büro destek ve iş destek faaliyetleri ile Bilgisayarların, kişisel eşyaların ve ev eşyalarının onarımı alt sektörlerinin öğrenme eğrileri ise dışbükeydir. Daha az bilgi yoğun piyasa hizmetleri kategorisinde yer alan alt sektörlerin ilgili dönemde ortalama öğrenme oranları incelendiğinde, en yüksek öğrenme düzeyinin 0,611 ile Büro yönetimi, büro destek ve iş destek faaliyetleri alt sektöründe gerçekleştiği görülmektedir.

Yüksek teknoloji bilgi yoğun hizmetler kategorisinde yer alan alt sektörlerin öğrenme eğrileri Bilgisayar programlama, danışmanlık ve ilgili faaliyetler ile Bilgi hizmet faaliyetleri alt sektörleri haricinde içbükeydir. Yüksek teknoloji bilgi yoğun hizmetler kategorisinde yer alan alt sektörlerin 2003-2017 dönemi itibariyle ortalama öğrenme oranları incelendiğinde, en yüksek öğrenme düzeyinin 0,759 ile Bilgisayar programlama, danışmanlık ve ilgili faaliyetler alt sektöründe gerçekleştiği tespit edilmiştir.

Diğer daha az bilgi yoğun hizmetler kategorisinde bulunan alt sektörlerin öğrenme eğrileri dışbükey bir biçime sahiptir. Bu kategoride yer alan Posta ve kurye faaliyetleri ile Diğer hizmet faaliyetleri alt sektörlerinde analiz döneminde ortalama öğrenme düzeyleri $(1,097$ ve 1,056$) 1$ değerinden büyük olduğu için ilgili alt sektörlerde unutma yaşanmıştır.

\section{SONUÇ}

Hizmet sanayi, ülkelerin kalkınması ve büyümesinde önemli roller üstlenen bir sektör konumundadır. Günümüzde, bu sektörün gelişimi ve rekabetçi yapısının güçlendirilmesi, teknolojik değişim ve dönüşüm hızına bağlıdır. Bu durum ise teknolojik öğrenme seviyesi ile yakından ilgilidir. Öğrenme eğrisi, herhangi bir sektörün teknolojik öğrenme düzeyini belirlemek için geçmişten günümüze kadar yaşanan süreç içerisinde sıklıkla kullanılmaktadır.

Bu çalışmanın amacı, 2003-2017 dönemi Türkiye'de Bilgi Yoğun Hizmetler alt sektörleri için öğrenme eğrilerinin şekillerini, kübik öğrenme modeli ile analiz etmektir. Kübik öğrenme modelinden elde edilen tahmin sonuçları, ilgili alt sektörlerde öğrenme veya ilerleme oranının zaman içinde değiştiğini göstermiştir. 2003-2017 yılları arasında, Bilgi Yoğun Hizmetler alt sektörlerinde ortalama öğrenme seviyeleri dikkate alındığında 37 alt sektörden 23'ünde öğrenme ve geriye kalan 14 alt sektörde ise unutma yaşanmıştır. Bu bağlamda, Bilgi Yoğun Hizmetler alt sektörlerinin genel anlamda iyi bir performans gösterdiklerini söylemek mümkündür. İlgili alt sektörler içerisinde 91 kodlu Kütüphaneler, arşivler, müzeler ve diğer kültürel faaliyetler alt sektörü söz konusu dönem için en yüksek ortalama öğrenme seviyesine sahiptir (0,548). Yani, 2003-2017 yıllar1 arasında Kütüphaneler, arşivler, müzeler ve diğer kültürel faaliyetler alt sektörünün üretimi için birim üretim maliyetleri, üretim düzeyinin her iki katına çıkması ile birlikte \% 45,2 oranında azalmıştır.

$\mathrm{Bu}$ çalışmada, farklı alt sektörlerin farklı öğrenme oranlarına ve dolayısıyla farklı öğrenme eğrilerine sahip oldukları görülmüştür. Bilgi yoğun hizmetler alt sektörlerin bazılarında başlangıç döneminden sonra daha iyi öğrenme gözlemlenirken, diğerlerinde bazı başlangıç ve bitiş dönemlerinde daha iyi öğrenme potansiyeli görülmüsstür. Ayrıca, bazı alt sektörlerde ise her yıl için öğrenme yaşanmıştır. Öğrenme eğrisinin olumlu etkileri daha iyi anlaşıldıkça daha düşük maliyetle daha iyi üretim ve teknolojik kararlar alınabilir. Sektörler arasındaki teknolojik farkl1lıklar, Ar-Ge harcamaları seviyesindeki farkl111klar ve üretim sürecindeki farkl11ıklar vb. her bir alt sektörün öğrenme eğrisinin şeklinin farklı olmasına neden olmaktadır. Ayrıca, firma ve sektöre özgü faktörler de öğrenme eğrisinin nasıl bir eğim göstereceğini belirlemektedir. Hükümetler, teknolojik öğrenmeyi 
veya ilgili alt sektörün unutkanlığını göz önünde bulundurarak yeniden düzenlenmesi gereken herhangi bir alt sektöre müdahale etmelidir.

Sonuç olarak, herhangi bir sektörde gerçekleşen öğrenme düzeyi, dönemden döneme, ülkeden ülkeye ve bölgeden bölgeye değişebilmektedir. Bu çalışmadan elde edilen sonuçlar, inceleme döneminde elde edilebilen veriler, kullanılan değişkenler ve analiz yöntemi ile sınırlıdır. Farklı dönem, değişken veya yöntemlerin kullanılması analiz sonuçlarının değişmesine yol açabilir.

Bilgi yoğun hizmetler alt sektörlerindeki öğrenme seviyeleri bu çalışmada mikro-ekonomik değişkenler göz önüne alınarak analiz edilmiştir. Teknolojik öğrenme seviyelerini etkileyebilecek makro-ekonomik değişkenler de analiz konusu olabilir. Bu çalışmanın sonuçlarının öğrenme eğrisi ile ilgili gelecekte yapılacak diğer çalışmalara 1şık tutması beklenmektedir.

Etik Beyanı

: Bu çalışmanın tüm hazırlanma süreçlerinde etik kurallara uyulduğunu yazarlar olarak beyan ederiz. Aksi bir durumun tespiti halinde ÖHÜIIBF Dergisinin hiçbir sorumluluğu olmayıp, tüm sorumluluk çalışmanın yazarlarına aittir. İlgili çalışmada kullanılan veriler 2019 yılında toplanmış ve analiz edilmiştir. Veriler 2020 yılı öncesi toplandığından etik kurul kararı gerekmemektedir.

Yazar Katkıları : Çalmaşur, çalışmada Giriş, Metodoloji, Ampirik Bulgular bölümlerinde ve (veri toplama, analiz vs. gibi) aşamalarında katkı sağlamıştır. Daştan, çalışmada Literatür Özeti, Metodoloji, Sonuç bölümlerinde ve (veri toplama, analiz vs. gibi) aşamalarında katkı sağlamıştır. Karaca, çalışmada Literatür Özeti, Metodoloji, Ampirik Bulgular bölümlerinde ve (veri toplama, analiz vs. gibi) aşamalarında katkı sağlamıştır.1. yazarın katkı oranı: \%40, 2. yazarın katkı oranı: \%30, 3. yazarın katkı oranı: \%30.

$\begin{array}{ll}\text { Çıkar Beyanı } & \text { : Yazarlar arasında çıkar çatışması yoktur. } \\ \text { Teşekkür } & \text { : Yayın sürecinde katkısı olan hakemlere ve editöre teşekkür ederiz. }\end{array}$

Ethics Statement $\quad$ : The authors declare that the ethical rules are followed in all preparation processes of this study. In the event of a contrary situation, ÖHÜIBF Journal has no responsibility and all responsibility belongs to the authors of the study. The data used in this study were collected in 2019 and the data were analyzed. Since the data are collected before 2020, an ethical committee decision is not required.

Author Contributions : Çalmaşur contributed in the Introduction, Methodology, Empirical Findings sections and stages (such as data collection, analysis etc.). Daştan made a contribution in the Literature Summary, Methodology, Conclusion sections and stages (such as data collection, analysis etc.). Karaca contributed to the Literature Summary, Methodology, Empirical Findings sections and stages (such as data collection, analysis etc.) in the study. Contribution rate of 1 nd the author: $40 \%$, Contribution rate of the 2 nd author: $30 \%$, Contribution rate of the $3 \mathrm{rd}$ author: $30 \%$.

Conflict of Interest $\quad$ : There is no conflict of interest among the authors.

Acknowledgement $\quad$ : We thank the referees and editor who contributed to the publication process.

\section{KAYNAKÇA}

Aduba, J. J., \& Izawa, H. (2018). Industry (economic)-wide learning: a comparative study of manufacturing and non-manufacturing sector in Japan. Asian Journal of Economics, Business and Accounting, 9(4), 1-14. https://doi.org/10.9734/AJEBA/2018/46859

Anzanello, M. J., \& Fogliatto, F. S. (2011). Learning curve models and applications: literature review and research directions. International Journal of Industrial Ergonomics, 41(5), 573-583. https://doi.org/10.1016/j.ergon.2011.05.001

Argote, L., Beckman, S. L., \& Epple, D. (1990). The persistence and transfer of learning in industrial settings. Management Science, 36(2), 140-154. https://www.jstor.org/stable/2661452

Argote, L., \& Epple, D. (1990). Learning curves in manufacturing. Science, 247(4945), 920-924. https://www.jstor.org/stable/2873885

Asgari, B., \& Gonzalez-Cortez, J. L. (2012). Measurement of technological progress through analysis of learning rates; the case of the manufacturing industries in Mexico. Ritsumeikan Journal of Asian Pacific Studies, 31, 101-119. http://en.apu.ac.jp/rcaps/uploads/fckeditor/publications/journal/RJAPS _V31.pdf 
Asgari, B., \& Yen, L. W. (2009). Accumulated knowledge and technical progress in terms of learning rate; a comparative analysis on the manufacturing industry and service industry in Malaysia. Asian Journal of Technological Innovation, 17(2), 71-99. https://doi.org/10.1080/19761597.2009.9668674

Asher, H. (1956). Cost-quantity relationships in the airframe industry. Report No. 291, RAND Corporation.

Badiru, B. A. (1992). Computational survey univariate and multivariate learning curve models. IEEE Transaction on Engineering Management, 39(2), 176-188. https://doi.org/10.1109/17.141275

Baloff, N. (1971). Extension of the learning curve-some empirical results. Operational Research Quarterly, 22(4), 329-340. https://doi.org/10.2307/3008186

Boston Consulting Group. (1970). Perspectives on experience. Boston: Boston Consulting Group.

Boston Consulting Group. (1973). The experience curve-reviewed II: history, perspectives. Boston: Boston Consulting Group.

Carlson, J. G. (1973). Cubic learning curves: precision tool for labor estimating. Manufacturing Engineering and Management, 71(5), 22-25.

Chung, S. (2001). The learning curve and the yield factor: the case of Korea's semiconductor industry. Applied Economics, 33(4), 473-483. https://doi.org/10.1080/00036840122474

Church, J., \& Ware, R. (2000). Industrial organization: a strategic approach. Boston: McGraw Hill.

De Jong, J. R. (1957). The effects of increasing skill on cycle time and its consequences for time standards. Ergonomics, 1(1,) 51-60. https://doi.org/10.1080/00140135708964571

Dick, A. R. (1991). Learning by doing and dumping in the semiconductor industry. Journal of Law and Economics, 34(1), 133-159. https://www.jstor.org/stable/725416

Dinler, Z. (2019). Mikro ekonomi, Bursa: Ekin Basım Yayın Dağıtım.

Dudley, L. (1972). Learning and productivity change in metal products. The American Economic Review, 62(4), 662-669. https://www.jstor.org/stable/1806108

Franceschini, F., \& Galetto, M. (2002). Asymptotic defectiveness of manufacturing plants: an estimate based on process learning. International Journal of Production Research, 40(3), 537-545. https://doi.org/10.1080/00207540110090948

Goldemberg, J., Coelho, S. T., Nastari, P. M., \& Lucon, O. (2004). Ethanol learning curve-the Brazilian experience. Biomass and Bioenergy, 26(3), 301-304. https://doi.org/10.1016/S0961-9534(03)001259

Hartley, K. (1965). The learning curve and its application to the aircraft industry. The Journal of Industrial Economics, 13(2), 122-128. http://www.jstor.com/stable/2097667

Jarmin, R. S. (1994). Learning by doing and competition in the early rayon industry. The RAND Journal of Economics, 25(3), 441-454. http://www.jstor.com/stable/2555771

Kalish, S. (1983). Monopolist pricing with dynamic demand and production cost. Marketing Science, 2(2), 135-159. http://www.jstor.org/stable/184114

Karaöz, M., \& Albeni, M. (2005). Dynamic technological learning trends in Turkish manufacturing industries. Technological Forecasting and Social Change, 72(7), 866-885. https://doi.org/10.1016/j.techfore.2004.09.005

Knecht, G. R. (1974). Costing technological growth and generalized learning curves. Operations Research Quarterly, 25(3), 487-491. https://doi.org/10.1057/jors.1974.82

Krajewski, L. J., Malhotra, M. K., \& Ritzman, L. (2015). Operations management: processes and supply chains. Essex: Pearson Education.

Levy, F. K. (1965). Adaptation in the production process. Management Science, 11(6), 136-154. https://doi.org/10.1287/mnsc.11.6.B136

Lieberman, M. B. (1984). The learning curve and pricing in the chemical processing industries. The RAND Journal of Economics, 15(2), 213-228. https://doi.org/10.2307/2555676

Majd, S., \& Pindyck, R. S. (1989). The learning curve and optimal production under uncertainty. The RAND Journal of Economics, 20(3), 331-343. https://doi.org/10.2307/2555574

Nadeau, M., Kar, A., Roth, R., \& Kirchain, R. (2010). A dynamic process-based cost modeling approach to understand learning effects in manufacturing. International Journal of Production Economics, 128(1), 223-234. https://doi.org/10.1016/j.ijpe.2010.07.016

Petrakis, E., Rasmusen, E., \& Roy, S. (1997). The learning curve in a competitive industry. The RAND Journal of Economics, 28(2), 248-268. https://doi.org/10.2307/2555804

Pramongkit, P., Shawyun, T., \& Sirinaovakul, B. (2002). Productivity growth and learning potentials of Thai industry. Technological Forecasting and Social Change, 69(1), 89-101. https://doi.org/10.1016/S0040-1625(99)00088-8

Salvatore, D. (2003). Microeconomics: theory and applications. New York: Oxford University Press.

Sinclair, G., Klepper, S., \& Cohen, W. (2000). What's experience got to do with it? sources of cost reduction in a large specialty chemicals producer. Management Science, 46(1), $28-45$. https://doi.org/10.1287/mnsc.46.1.28.15133 
Spence, A. M. (1981). The learning curve and competition. Bell Journal of Economics, 12(1), 49-70. https://doi.org/10.2307/3003508

Sultan, R. (1974). Pricing in the electrical oligopoly. Boston: Harvard University Press.

Tan, W., \& Elias, Y. (2000). Learning by doing in Singapore construction. Journal of Construction Research, 4(2), 151-158. https://doi.org/10.1142/S1609945103000431

Waldman, D. E., \& Jensen, E. J. (2013). Industrial organization: theory and practice. Boston: Pearson Education.

Wright, T. P. (1936). Factors affecting the cost of airplanes. Journal of the Aeronautical Sciences, 3, 122-128. https://doi.org/10.2514/8.155

Yelle, L. E. (1979). The learning curve: historical review and comprehensive survey. Decision Science, 10(2), 302-328. https://doi.org/10.1111/j.1540-5915.1979.tb00026.x 